\title{
"Standing" for Pressure Groups and the Representative Plaintiff
}

\author{
Barry Hough ${ }^{\star}$
}

"It is manifest, that men who are in absolute liberty may ... give Authority to One man, to represent them every one": Hobbes, Leviathan.

The common law has shown too great a respect for the individual. Pound expressed it this way: "The common law ... is concerned, not with social righteousness, but with individual rights. It tries questions of the highest social import as mere private controversies between John Doe and Richard Roe. And this compels a narrow and one-sided view ...".1

In public interest litigation, therefore, the law has required that justice be done for the benefit of the individual ${ }^{2}$ who seeks to vindicate his private legal rights. Pound castigated this sanctity of the individual as damaging "for the needs of society". ${ }^{3}$ Indeed, courts are perceived as condoning illegality where a remedy is denied only for want of locus standi in the plaintiff. ${ }^{4}$ Further, such a result undermines legislative policy by frustrating the enforcement of legal rights and interests. And rights without remedies are mere "delusions". 5

The reforms introduced by the new R.S.C. Ord. 53 have certainly liberalized the standing doctrine. ${ }^{6}$ The question to be addressed in this article is whether these changes have been sufficiently profound to permit litigation in the public interest by representative individuals or pressure groups who seek the intervention of the court on behalf of others more closely affected and, ultimately, for the benefit of

* Lecturer in Law, University College of Wales, Aberystwyth.

1. (1905) 5 Columbia L. Rev. 339, at p. 346.

2. A late example of this approach can be seen in Gouriet v. Union of Post Office Workers [1978] A.C. 435. For an account of the development of the law of locus standi, see Wade $A d$ ministrative Law 6 th ed. (1988), at pp. 688 et seq.

3. Supra n. 1, at p. 344 .

4. Such a criticism was ventured by Professor Wade of $R$. v. Customs and Excise Commissioners, ex $p$. Cook [1970] I W.L.R. 450: (1978) 94 L.Q.R. 5.

5. Per Sir K. Schiemann, [1990] P.L. 342, at p. 343; see also Rudolph von Ihering, Der Kamp ums Recht (1872).

6. See, e.g., the dictum of Slade LJ, in R. v.H.M. Treasury, ex p. Smedley [1985] Q.B. 657, at p. 669; also $R$. v. Inland Revenue Commissioners, ex p. Federation of Self-Employed and Small Businesses Ltd. [1982] A.C. 617 (per Lord Diplock) and 656 (per Lord Roskill). 
the public. ${ }^{7}$ The possibility of representative litigation is particularly important for many groups of individuals in society who, whether from a lack of resources or other forms of disadvantage, would otherwise not be able to seek a remedy in their own right. These are precisely the individuals who are most likely to be in need of the protection conferred by the rights in issue. Pressure groups or public spirited litigants frequently possess the resources and expertise necessary to ensure the vindication of rights or interests enjoyed by others either by promoting suitable "test" cases, or by proceeding in their own name. "Test" cases are not always an appropriate solution, however, ${ }^{8}$ and, if the organisation is then unable to proceed in its own name, the rights or interests of those without the resources to defend them may be prejudiced for want of enforcement.

Lord Diplock averted to the question of representative and pressure group litigation in the Fleet St. Casuals case, ${ }^{9}$ in which he concluded:

"It would, in my view, be a grave lacuna in our system of public law if a pressure group, like the federation... were prevented by outdated rules of locus standi from bringing the matter to the attention of the court to vindicate the rule of law and get the unlawful conduct stopped." 10

Almost ten years after their lordships' decision it is proposed to consider the extent to which pressure groups and other representative litigants have been allowed to challenge a breach of public duty affecting others in a greater measure than themselves.

Proceedings such as these raise complex questions. Quite apart from whether, in public interest litigation, justice is done for the benefit of the public, ${ }^{11}$ there remains the question of whether the locus standi rules fall to be applied solely against the representative litigant or whether the court can have regard to the interests of the represented group to fortify the position of the representative. If representation is to be allowed, in what circumstances is it legitimate and who is to be regarded as a competent representative?

In recent years, the courts appear to have given a warmer but not unqualified welcome to representative or group proceedings. Developments have nevertheless been compromised by a failure to develop principles which will define their proper

7. The controversy surrounding locus standi has become more prominent recently: see, e.g., Schiemann, supra n. 5 , in which a reconsideration of the purpose served by the rules is urged, and $P$. Cane, [1990] P.L. 307 in which standing for representative groups is advocated as a necessary assistance for not only the "poor and under privileged" but also members of the public whose protector - the Attorney-General - may not take action against Central Government.

8. See, e.g., Wilkeley, (1985) 135 N.L.F. 1123 discussing the strategy of the Child Poverty Action Group in $R$. v. Secretary of State for Soctal Services, ex p. Child Poverty Action Group and the Greater London Council [1985] The Times, 8th August.

9. R. v. Inland Revenue Commissioners, ex p. Federation of Self-Employed and Small Businesses Ltd. [1982] A.C. 617.

10. Ibid., at p. 644 .

11. This was the rationale of allowing a more liberal standing requirement to operate in the case of the prerogative orders. See, e.g., Craig, Administrative Law 2 nd ed. (1989), especially at p. 365, and Wade, (1978) 94 L.Q.R. 5 . 
scope. In some cases the issue of principle has been passed over. Alternatively, the courts have merely stretched the traditional approach by awarding locus standi to a representative litigant on the ostensible ground that he satisfies the orthodox rules in his own right. No doubt this is a just result but it has caused a perceptible distortion of the locus standi rules. Such an approach would have been unnecessary had the courts realized that different questions are raised in this type of case which make it unsuitable for the analysis normally applied in single party proceedings.

\section{The orthodox approach: the Fleet St. Casuals case ${ }^{12}$}

The Fleet St. Casuals case illustrates the traditional, if somewhat conservative, approach to representative type litigation. In this case, the House of Lords trod the well-beaten path in seeking to measure the sufficiency of the interest of the representative litigant, as it had done in the earlier Gouriet case. ${ }^{13}$ In Fleet St. the applicant for judicial review was an association which represented the views of the self-employed person and small businessman, alleging that the Inland Revenue had abused its powers in undertaking not to pursue certain tax arrears owed by a group of Fleet St. workers.

Their lordships examined whether the Federation had a sufficient interest and, in order to answer this, focused upon the interests of its members. The speeches do, however, reveal a considerable difference of opinion as to the role and standard of the sufficiency of interest required. ${ }^{14}$ The majority decided that in this context the federation did not have a locus standi to represent its members. The assessment of taxes was a confidential matter between the Revenue and the individual taxpayer in which, generally, another taxpayer could not have an interest. Therefore, as Lord Wilberforce observed: "an aggregate of individuals each of whom has no interest cannot of itself have an interest". 15

Their lordships kept open the possibility that in exceptional circumstances, an actio popularis could be desirable. Most agreed that serious unlawful conduct by the defendant would be capable of affording locus standi for the benefit of an

\section{Supra n. 9.}

13. Supra n. 2.

14. It was held by the majority that standing is to be judged in relation to the legal and factual context (see, e.g., the speeches of Lords Wilberforce [1981] 2 W.L.R. 722, at p. 727, Lord Scarman at pp. 748-49 and Lord Roskill at p. 753). Lord Fraser, however, thought that it would be relevant to consider more narrowly the statute under which the duty alleged to have been breached arises to ask whether the applicant has an express or implied right to bring his application (at p. 742). It is respectfully submitted that such an approach is fraught with difficulty because of the difficulty in identifying legislative intention. A similar test was briefly adopted in the United States: see $A$ ssociation of Data Processing v. Camp 397 US 150 (1970) but later apparently abandoned: Duke Power v. Carolina Environmental Study Group 438 US 59 (1978).

15. [1982] A.C. 617, at p. 633; see also R. v. Secretary of State for the Environment, ex p. Rose Theatre Trust Co. [1990] 1 All E.R. 754, Schiemann J. 
applicant who might otherwise lack it. ${ }^{16}$

The majority held, however, that the applicant must demonstrate a sufficient interest in relation to the merits of the case itself. This is significant because, as will be demonstrated, representative litigants have been awarded locus standi, not by virtue of their relationship with the legal and factual issues, but with their relationship of proximity with a group of others who do have such an interest. This is to adopt a wholly different principle from that enunciated in the Fleet St. case.

Since, however, an association is not competent to advance the interests of its members unless their interest was itself "sufficient"17 the Federation was not competent to seek judicial review in these circumstances.

The decision is strictly orthodox in its approach: the Federation, as the applicant, was treated as the effective unit in the litigation. This is the stance which the courts will normally adopt. Yet this orthodox model has had to endure a certain measure of strong-arming to produce acceptable results. In reality a Nelsonian eye is often turned to the traditional rules enabling the court to recognise that the real unit in the matter is not the representative plaintiff but those represented who are absent from the court-room.

\section{The new technique}

$R$. v. Social Services, ex p. Child Poverty Action Group and the Greater London Councilis is one of several decisions which suggest the abandonment of the traditional model despite apparent lip-service to it. Here the Child Poverty Action Group (C.P.A.G.) was awarded locus standi to challenge the administration of the supplementary benefit system on behalf of a group of unidentified claimants whose cases were not reviewed within the meaning of statute. Woolf J reasoned that the C.P.A.G. was a body "designed" to represent the interests of claimants and that it was a proper challenger. In contrast, the G.L.C. had no cognisable status in this matter: it had attempted to represent the public interest by usurping the role of the Attorney-General. An appeal to the Court of Appeal on the merits was subsequently successful ${ }^{19}$ but the question of locus standi was left open.

Although Woolf J ostensibly adopted the orthodox technique by examining the position of the C.P.A.G., the resulting award of locus standi is not convincing as an application of it. The C.P.A.G. was not a welfare claimant; and although a charity

16. Ibid., per Lord Wilberforce at p. 633; Lord Fraser at p. 647; Lord Roskill at p. 662. Lord Scarman also held that the Federation lacked locus standi because it could not show a breach of duty by the Revenue on the merits (at p. 654).

17. Cf., R. v. Chief Adjudication Officer, ex p. Bland [1985] The Times, 6th February (infra) and the Rose Theatre case, supra n. 13, as illustrations of this principle.

18. [1984] The Times, 16th August.

19.R. v. Secretary of State for Social Services, exp. Child Poverty Action Group and the Greater London Council [1985] The Times, 8th August. The same course was also adopted in $R$. v. Secretary of State for Social Services, ex p. CPAG and Others [1989] 1 All E.R. 1047. As Lord Roskill observed in the Fleet St. Casuals case, "refusal of the application on the merits ... implies that the [standing] question has been answered affirmatively": [1982] A.C. 617, at p. 645 . 
dedicated to the relief of poverty amongst children and families with children, it could not be said that it had any private interest in the outcome of the proceedings. In essence, it was seeking to assert the interests of all unidentified claimants and the public. Woolf $\mathrm{J}$ was forced to disguise this by finding that the body was "designed" to assist welfare claimants. This approach was certainly not a recognised one since English law has never permitted a "private attorney-general" to appoint himself responsible for matters of public interest. ${ }^{20}$ Moreover, such a group encountered severe difficulty in the subsequent Rose Theatre case ${ }^{21}$ which demonstrates that the concern of a single issue pressure group with one aspect of proper administration may not be sufficient to give it standing to sue. So the proposition that representation was appropriate because of the stated purpose of the C.P.A.G. is not necessarily convincing.

The conclusion which must be drawn is that, in essence, the C.P.A.G.'s status was "transferred" to it. The source of this can only have been either the rights and interests of the individuals directly prejudiced by the action in question or the public interest in having the matter settled. On either interpretation, the substance of this decision appears to have repudiated the orthodox standing rules.

It is worthwhile considering some of the ingredients in the C.P.A.G. case. As in the Royal College of Nursing case ${ }^{22}$ (considered infra), the alleged breach of public duty would have amounted to a matter of serious and legitimate public concern. The C.P.A.G. was clearly perceived as a body capable of providing effective advocacy of the legal issues by virtue of its welfare activities and, as a separate matter, it had a relationship of proximity with the group represented. ${ }^{23}$ The absence of such a relationship of proximity also explains his lordship's decision that the G.L.C. did not have standing to sue in the C.P.A.G. case. Whilst the C.P.A.G., active in welfare matters, enjoyed a closer and more immediate concern with the legal issues, the G.L.C. possessed responsibilities of an entirely different and diverse nature. ${ }^{24}$

Since the real concern of each body lay in ensuring the due administration of the benefit system, it is not entirely satisfactory to distinguish them on the grounds that one lacked a sufficient interest in the matter and the other did not, nor by

20. E.g., Gouriet v. Union of Post Office Workers [1978] A.C. 435; but also R. v. Secretary of State for the Environment, ex p. Rose Theatre Trust Co. [1990] 1 All E.R. 754 in which it might also have been observed that the Trust was a single issue pressure group "designed" to effect a change in policy regarding the scheduling of the Rose Theatre as an ancient monument.

21. Supra n. 20.

22. [1981] A.C. 800 .

23. Perhaps it would be more satisfactory to regard the relationship of proximity as existing between those claimants with children and the C.P.A.G. rather than between the latter and all claimants regardless of whether or not they were parents. If the C.P.A.G. had defined its representation accordingly the result would not have differed since a successful challenge would have benefited all relevant claimants.

24. The decision to refuse locus standi to the G.L.C. has been criticised on the grounds inter alia that it had run benefits take up campaigns: see Wilkeley, (1985) 135 N.L.F. 1123. 
pointing to their different raisons d'être. ${ }^{25}$ Arguably, both were acting as "private attorneys-general". The only real distinction between them lay in their different relationships with the claimants, and this is the crucial issue affecting locus standi. The only test which distinguishes them is therefore that based on proximity.

Proximity of relationship was also treated as governing the standing issue in $R$. v. Chief Adjudication Officer, ex p. Bland. ${ }^{26}$ Here a striking miner, his union, the National Union of Mineworkers, and the Trades Union Congress each sought judicial review of the Chief Adjudication Officer's advice regarding deductions from supplementary benefits when individuals were taking part in an industrial dispute. One of the N.U.M.'s principal objects was to protect the interests of its members and it had called the strike which resulted in their claiming supplementary benefit. The court held that the N.U.M. had locus standi, by virtue of its relationship with the striking miners. This is of great significance since it clearly demonstrates the new approach in representative type litigation. A "sufficient interest" is not found "in the matter to which the application relates" but in the proximity of relationship which the representative has with the group represented who in turn have a cognisable interest in the substantive issues.

Applying this same test it can be seen that the T.U.C.'s relationship with Bland and the striking miners was, in the court's own words "too remote" to establish locus standi even though one of its objects was the protection of workers in all unions affiliated to it.

\section{Proceedings outside the application for judicial review}

Section 31 of the Supreme Court Act 1981 applies the sufficiency of interest formula to applications for judicial review. Locus standi under the old procedure is not affected by s. 31 and it is likely that it continues to be governed by the more restrictive locus standi requirement enunciated in the Gouriet case. ${ }^{27}$ This is highly significant because, if representation by non-interested litigants of third party interests was permissible under the Gouriet regime, it would be difficult to resist its impact under the new judicial review procedure where the safeguard of the leave requirement operates to prevent abuses of the judicial process. ${ }^{28}$

The decision of the House of Lords in the Gouriet case that the plaintiff's locus standi must rest upon his having a legal or equitable right of his own at issue or upon his having suffered "special damage", appeared to signal that pressure group and similar litigation should be exiled from proceedings outside of the application for judicial review. Fortunately, some signals, no matter how lucid, are received

25. If the Child Poverty Action Group was permitted to represent all unidentified claimants, and not just those with children, it is difficult to distinguish its position from that of the G.L.C. using orthodox principles. Essentially both were policing the benefits system.

26. [1985] The Times, 6th February.

27. [1978] A.C. 435, although this may subsequently have been reconsidered: Liverpool Daily Post and Echo Newspapers p.l.c. v. Pickering [1990] 1 All E.R. 335, especially per Lord Donaldson MR at p. 345. 28. Sir H. Woolf, [1986] P.L. 220. 
with a blind eye with welcome results. This appears to have been the case following Gouriet, for the House of Lords subsequently allowed a representative body to advocate the interests of its members and others.

In The Royal College of Nursing v. D.H.S.S. ${ }^{29}$ in an action also begun by writ seeking a declaration, the Royal College of Nursing was permitted to test the legality of a circular issued by the Department of Health and Social Security. The Circular purported to clarify the ambit of the role of nursing staff in abortion cases by suggesting that, provided an abortion was commenced by a registered medical practitioner, the remainder of the process could be carried out by nurses. If the Circular did not comply with the criminal law, nurses risked prosecution.

The objection might have been raised that the action was initiated by the R.C.N., not one of the nursing staff placed at risk by the circular. The traditional locus standi rules for declaration ${ }^{30}$ were that the applicant should show that a private legal right of his own was at issue or that he had suffered special damage or that the threat of prosecution threatened that such damage might be inflicted in the future. The nurses individually fulfilled this requirement. It would have been possible for one of the nurses, perhaps representing all others, to argue the matter in court. More problematic was the position of the Royal College which did not itself become involved in the abortion process. Its rights were unaffected by the circular and to the extent that it suffered at all, it would certainly have been to a far lesser degree than the nurses. Thus it could not have relied on the special damage rules. ${ }^{31}$

The House of Lords, rejecting the R.C.N.'s case on the merits, unfortunately failed to avert expressly to the locus question. The matter seems to have been assumed sub silentio. Yet had the R.C.N.'s standing been challenged, it is difficult to accept that those objections would have succeeded. In matters of this kind, the courts have openly expressed concern at the effect of the locus rules. Woolf $\mathrm{J}$, for example, has stated: ". . . it would be regrettable if a court had to come to the conclusion that in a situation where the need for intervention of the court had been established this intervention was prevented by rules as to standing." 32 This, of course, questions the rationale of the locus standi doctrine, the logic of which is precisely to prevent the courts from intervening notwithstanding any need to do so. Nevertheless, in the R.C.N. case, the substantive issues were of overwhelming public concern and it was necessary to clarify the legal status of the circular both for the sake of the nurses and to address public anxiety. It would have been highly

29. [1981] A.C. 800 .

30. The traditional locus standi rules for declaratory relief are considered in Gouriet v. Union of Post Office Workers, supra n. 27, and also in Barrs v. Bethell [1982] 1 All E.R. 106, at p. 114. For the "special damage" rules see, e.g., Benjamin v. Storr (1874) L.R. 10 C.P. 400, at p. 407 per Brett J; Stoke Parish Council v. Price [1899] 2 Ch. 277; Stockwell v. Southgate Corpn. [1936] 2 All E.R. 1343, at pp. 1351-2. 31. An example of litigation by trade associations is to be found in London Association of Shipowners and Brokers v. London and India foint Docks Committee [1892] $3 \mathrm{Ch}$. 242 in which a trade association lacked locus standi to sue.

32. R. v. Attorney General, ex p. Imperial Chemical Industries p.l.c. [1985] 1 C.M.L.R. 588, at p. 618. 
unsatisfactory for the courts to fail to offer guidance as to the legality of the nurse's actions by virtue of the R.C.N.'s possible lack of locus standi.

Moreover, the R.C.N. was fully cognisant of the issues involved and thus capable of providing effective advocacy of the nurses rights; indeed, the College in so far as it was the corporate advocate of nurses' interests, enjoyed a relationship of proximity with the nurses. ${ }^{33}$ Significantly, therefore, there are unmistakeable parallels with the C.P.A.G. and G.L.C. cases.

\section{"Constructive" representation: the initiative of the court}

The courts themselves appear able to convert litigation begun in a single party form into one of "constructive" representation in order to salvage the litigation from locus standi problems. To do so is to abandon the traditional model, but the tradition of allegiance to orthodoxy does not deter such radicalism. In $R$. v. London Borough of Lambeth, ex $p$. Sharp, ${ }^{34}$ for example, a local planning authority proposed to grant itself planning permission for a certain development. The application was required to be published specifying a date by which any objections should be received. The date was omitted from the published notice. The applicant for review, however, had only read the notice and taken action after the expiry of the probable date by which objections ought to have been made. Even if the notice had contained a date, the applicant would still have been out of time: he had simply seen it too late to take action. Strictly, he had not been prejudiced by the local authority's omission. His concern essentially was in the lawful administration of the planning system.

It was held, however, both at first instance and on appeal, that he had locus standi to seek review and the court proceeded to quash the planning permission in question. In the appeal, Woolf LJ observed:

"... he is making the application not only on his own behalf but, in effect, on behalf of the public. In considering whether or not relief should be granted, the court, in my view, must have very well in mind the fact that regulations such as the one under consideration are designed to give the public generally notice of proposals of this sort." 35

This appears to be an extreme example ${ }^{36}$ in which the interest of the public and not the individual constitutes the standing to advance the substance of the claim.

Is there a consistency of approach which unifies Exp. Sharp, the C.P.A.G. and the R.C.N. cases? Turning first to the nature of the breach of public duty, it might be argued that Sharp's case was less convincing than, for example,the R.C.N. case.

33. The synonymity of interest means, in effect, that it was as if the nurses themselves were before the court. This is essentially the approach adopted in the United States: Hunt v. Washington State Apple Advertising Com. 53 L Ed. 2d 383 (1977).

34. (1986) 55 P \& C.R. 233.

35. Ibid., at p. 240 (italics added).

36. This approach is not an unprecedented one: see the judgment of Lord Denman CJ in Ricketts v. Bodenham (1836) 4 Ad. \& E. 433, at p. 441. 
The latter involved serious questions affecting the right to life which demands judicial intervention rather more persuasively than, say, the publication rules in planning matters. But it would appear that the gravity of the possible breach of duty is not necessarily determinative in itself: it must be considered alongside other factors. One influential consideration in $E x p$. Sharp may have been that the ultra vires action affected a large number of individuals but no one individual in particular. If the applicant's action failed on locus grounds, it was unlikely any other citizen could succeed. Thus it may have been that the implied representation was used as a device to give some embodiment to the otherwise abstract public interest. If this is so, Sharp suggests that even where the breach is not of one of the highest or most sacrosanct forms of public duty, but the harm it causes is diffuse, a representative status may possibly be employed as a device for vindicating the public interest. ${ }^{37}$ Even so, the decision must be the high-water mark of the public interest model of judicial review and the consequent reluctance to see review as merely a system for defending the private rights of the applicant. Such reasoning can arguably be made to apply in every case in which a litigant would wish to act as a "private attorney-general" with obvious effects for the future survival of the locus standi doctrine. If correct, it would threaten to erode the entire doctrine of standing since any public litigation can be seen, to a greater or lesser extent, to represent the public interest.

Exp. Sharp is not the only instance in which the courts have allowed the applicant to draw strength from the interests of the public at large. In $R$. v. Felixstowe fustices, ex p. Leigh, ${ }^{38}$ for example, the applicants, a newspaper and a journalist, sought judicial review of a policy of magistrates not to reveal their identities. The journalist had not been present in court during the trial in question but merely wished to comment on the manner in which the trial had been reported in other newspapers.

On behalf of the justices, it was objected that the journalist's position was akin to that of a pressure group since he had not been present in court and that he had no cognisable interest in the matter. Nevertheless, the court held that the role of the press as guardian and watchdog of the public interest gave the journalist locus standi to seek a declaration but not for a mandamus. The ingredients which may have led to such a result are interesting: as in the R.C.N. and C.P.A.G. cases, the resolution of the substantive issues was manifestly in the public interest and, in this case, the court found that the justices were acting unlawfully. The court was clearly reluctant to find its hands tied by locus objections and so there was an award of standing to a plaintiff whose own position, whilst not perhaps nominal, certainly drew heavily upon his perceived characteristics as a representative of the public interest in open justice. The desire, however, to adhere to a traditional approach defining the unit of litigation as the journalist plaintiff alone, forces the court to

37. Contrast, e.g., Gouriet v. Union of Post Office Workers [1978] A.C. 435 and R. v. Secretary of State for the Environment, ex p. Rose Theatre Trust Co. [1990] 1 All E.R. 754.

38. [1987] 2 W.L.R. 380. 
adopt what might ostensibly be regarded as a distortion of locus standi principles ${ }^{39}$ for it is difficult to distinguish his position from that of, for example, the G.L.C. in the C.P.A.G. case, or, more generally, any public spirited litigant concerned at an abuse of power.$^{40}$ In sum, the proof of illegality and the importance of the subject matter seems to permit "constructive representative litigation" by individuals effectively acting as "private attorneys-general".

Representative litigation is also a possibility acknowledged in diverse strands of authority outside of the above categories. Such developments may serve to bestow some legitimacy on the decisions already surveyed since they betray an essential community of approach from which a general principle may be derived. It is proposed to look at representative proceedings and class actions both in English and United States Federal Law, and also the litigation by a representative of a third party's constitutional rights in the United States.

\section{Representative proceedings under R.S.C. Ord.15 r. 12.}

Historically, the courts have permitted one self-appointed individual to represent a class of individuals. The governing conditions are that all must demonstrate "one common interest in all the objects of the suit". ${ }^{41}$ Neither the leave of the court nor a representation order are required before this form of proceeding can be employed. ${ }^{42}$ It has been stated that there must be a "common interest", a "common grievance" and the relief sought must be beneficial to all whom the plaintiff seeks to represent. ${ }^{43}$ Thus a pre-condition to a representative action is that all must share a "unity of interest" in the action. This is reflected in R.S.C. Ord. 15 r. 12 which now provides:

"Where numerous persons have the same interest in any proceedings ... the proceedings may be begun . . . by or against any one of them representing all or as representing all except one or more of them" (emphasis supplied).

In such a case, all members of the group represented are bound by the decision in the case. ${ }^{44}$

Representative proceedings have been employed principally in private law but need not be so confined. A significant feature of these proceedings has been that the courts have permitted a self-appointed representative to take proceedings the effect of which may be to bind others as to their legal rights without their consent.

39. It is difficult to distinguish the Rose Theatre case, supra n. 36, e.g., and also, perhaps, Holmes v. Checkland [1987] The Times, 15 April.

40. Journalists have also been held to have standing in R. v. Reigate $\mathcal{F}$, ex p. Argus Newspapers (1985) 5

Cr. App. R. (S) 181 and R. v. Arundel ff, ex. p. Westminster Press Lid. [1985] I W.L.R. 708.

41. Calvert, Parties to Suits in Equity (1837), p. 42.

42. In an application for judicial review the leave requirement would still operate and this could provide an opportunity to filter out representation which would not properly safeguard the interests of those represented. But there would be no such protection if the proceedings were begun by writ.

43. Per Lord Macnaghten in Duke of Bedford v. Ellis [1901] A.C. 1, at p. 8; see also per Sir Raymond Evershed MR in Smith v. Cardiff Corporation ]1954] 1 Q.B. 210, at p. 221.

44. Rules of the Supreme Court, Order 15 rule 12 (3). 
This is so notwithstanding the general prohibition on the litigation of third party rights. ${ }^{45}$ Since this is an acknowleged means of resolving disputes concerning private legal rights, there would seem to be little objection to its use in public law which is not often concerned with the strict legal rights of the parties. The principles governing representation in this context may vindicate parallel developments in public law. Representative proceedings, whether brought under R.S.C. Ord. 15 r. 12 or informally, as in, for example, the C.P.A.G. case, raise similar questions, and it would not seem desirable to have radically different sets of rules for each type of representative process. Proceedings under R.S.C. Ord. 15 r. $12 \mathrm{do}$, therefore, provide a ready-made framework of rules which could constitute at least the foundation for the evolution of representative style proceedings for judicial review. It is particularly significant that strict observance of the locus standi requirements has not been a feature of representative proceedings under R.S.C. Ord. 15 r. 12 in private law, and it seems paradoxical to insist upon strict observance in public law. This may lend some support to the locus standi developments in public law which have already been surveyed.

The policy of the courts has usually been to adopt a liberal approach towards the representative action under R.S.C. Ord. $15 \mathrm{r} .12 .{ }^{46}$ This has required some re-interpretation of the requirements of the "unity of interest" principle.

\section{The importance of the "unity of interest"}

The "unity of interest" theory, requiring the representative plaintiff and the class represented to have the "same interest" in the proceedings, would suggest that any locus standi requirement must be satisfied by each of them without exception. Conversely, a departure from the "unity of interest" approach towards a "substantive" approach ${ }^{47}$ would permit differences of interest and, possibly, an evolution of sui generis standing rules in this context.

Practice both in England and the United States, has been to dilute the "unity of interest" requirement, yet on this side of the Atlantic at least some common interest must be identified before the representation is appropriate. In essence, however, the courts here, as in the United States, have begun to experiment with a

45. One example of which is the doctrine of privity of contract: Dunlop Pneumatic Tyre Co. Ltd. v. Selfridge $\mathcal{E}$ Co. Ltd. [1915] A.C. 847.

46. The modern principles of the representative action were enunciated by Lord Eldon in such cases as Adair v. New River Co. (1805) 11 Ves. 429 and Cockburn v. Thompson (1809) 16 Ves. 321. In commenting upon these decisions in Duke of Bedford v. Ellis, Lord Macnaghten observed that "Lord Eldon took as broad and liberal a view on this subject as anybody could desire": [1901] A.C. 1, at p. 10. This policy was applied by his lordship in the Ellis case and has been followed ever since: see fohn v. Rees [1969] 2 All E.R. 274; and most recently in Irish Shipping v. Commercial Union Assurance Co. p.l.c. [1989] 3 All E.R. 853 and Chrzanowska v. Glaxo Laboratories Ltd. [1990] The Independent, March 13. 47. Here the court acts for the sake of the group represented to redress the grievance inflicted upon them by the defendant. The locus standi of the representative would not be considered to be of primary significance; his status would be nominal. The required adversity is found to exist between the defendant and the class: see Chayes, (1976) 89 Harv. L. Rev. 1318, especially pp. 1353 et seq.. The community of interest theory is also discussed at pp. 1331 et seq. 
different conceptual basis for representative proceedings. This is "substantive" in character ${ }^{48}$ and permits the court to resolve the dispute between those whose rights or interests are affected and the defendant despite different interests inter se or different interests as between themselves and the representative plaintiff. In some cases, the necessary adversarial positions are essentially those of the class represented and of the defendant and the courts have sometimes shown little concern with the ability of the representative to satisfy the normal locus standi rules.

\section{The evolution of the "unity of interest" requirement}

The dilution of the "unity of interest" requirement can be witnessed in a series of decisions. In $\mathfrak{f} o h n$ v. Rees, ${ }^{49}$ for example, where a representative action was brought by a chairman of an unincorporated association on behalf of all members of the association, a unity of interest was held to exist even though some members were actively hostile to his claims. Megarry J stated:

"Some may support one faction, some another. But if the named parties to the action together put forward every view that is seriously advanced, I cannot see that any real harm is done to a person whose part in the action is merely that he is represented by the plaintiff, even if the plaintiff is supporting a different cause, provided that there is a defendant who does stand for the cause espoused by the person being represented: actions are decided by reference to justice according to law, and not by counting heads. The remedy for someone who is not consoled by this thought is . . for him to apply to be joined as a defendant." 50

The idea of a "common interest" was further extended in M. Michaels (Furriers) Ltd. v. Askew. ${ }^{51}$ Here an injunction was granted by the Court of Appeal against named defendants representing themselves and all other members of an unincorporated pressure group to restrain the picketing of the plaintiff's premises. Members of the pressure group, neither named nor before the court, some of whom may not even have taken part in the action, were made subject to the injunction. Yet some of them might have raised objections to the manner of the picketing which might have allowed them separate defences and therefore precluded their having a common interest in the proceedings. Nevertheless, the Court held that the community of interest lay in the common objectives which all members of the group shared in campaigning against the fur trade. ${ }^{52}$ fohn v. Rees and M. Michaels (Furriers) Ltd. v. Askew suggest that the primary consideration is essentially the substantive one: what are the legal merits of the case as a whole?

\section{Ibid.}

49. [1969] 2 All E.R. 274.

50. lbid., at pp. 283-4.

51. (1983) 127 S.J. 597.

52. Protection for the absentee class members was found to exist in the rule which prevents enforcement of the judgment against them without the leave of the court: $c f . N I R E X$ Ltd. v. Barton [1986] The Times, Oct. 14th. These decisions are discussed by K. Uff, (1987) 6 Civ. Y. Q. 15. 
This subordinates the question of the legal identity of the individual asserting those rights leaving the court free to address the merits. In so far as there is an adherence to the "unity of interest" requirement, it seems capable of being satisfied by having regard almost to the lowest common denominator in the action: the membership by all individuals of the association in question..$^{53}$

That this may have implications for locus standi rules can be seen in the House of Lords' decision in Duke of Bedford v. Ellis ${ }^{54}$ which is the leading decision on representative proceedings. The judgment of Lord Macnaghten has come to be regarded as classical ${ }^{55}$ and definitive of the courts' jurisdiction. In brief, the facts were that six named plaintiffs sought to represent a class of other market traders in an action against the owner of the market alleging that the latter had violated certain rights enjoyed by the traders under statute. The difficulty was that the statement of claim alleged that the Duke had breached the Act in relation to certain classes of trader and types of pitch. None of the named plaintiffs in their personal capacity, however, asserted a cause of action in some of the matters raised, although clearly some class members would have such rights at issue. The Duke applied to have the claim struck out.

By a majority, the House of Lords held that the plaintiffs could maintain their claims notwithstanding their lack of a personal stake in some of the matters raised. Lord Macnaghten's reasoning is strongly biased towards a substantive approach which focuses upon the group's grievances advocated by the claimants as its representatives rather than on technical locus qualifications of the representative plaintiffs themselves. He observed:

"If the persons named as plaintiffs are members of a class having a common interest, and if the alleged rights of the class are being denied or ignored, it does not matter in the least that the nominal plaintiffs may have been wronged or inconvenienced in their individual capacity. They are none the better for that and none the worse. They would be competent representatives if they had never been near the Duke." 56

Lord Macnaghten clearly envisaged that the class representatives should be representatives of a class; a complete homogeneity of personal interest in the outcome is clearly not required. He observed that it is the rights of the class which are denied or ignored; the class representatives need not share those rights: they are not disqualified even if they are not even inconvenienced by the unlawful actions of the defendant. He made the point unequivocally by stating that they have a purely "nominal" status. Clearly it is the substantive claims of the class which prevail over the qualifications of the individuals who assert those claims.

53. See also the decision of Hirst J in Pan Atlantic Assurance Co. v. Pine Top Insurance Co. Ltd. [1988] 2 Lloyd Rep. 505 in which his lordship followed Megarry J's decision in fohn in legally similar circumstances.

54. [1901] A.C. 1.

55. See, per Megarry J, in fohn v. Rees, supra n. 51: also Smith v. Cardiff Corpn. [1954] 1 Q.B. 210, at p. 219, per Sir Raymond Evershed MR.

56. [1901] A.C. 1, at p. 7 . 


\section{The U.S. experience: class actions and the "standing doctrine" 57}

The US courts ostensibly adhere to orthodox standing rules where the challenge is brought by an individual or association seeking to act in a representative capacity. The requirements will normally be satisfied only where the representative alleges some injury to himself. ${ }^{58} \mathrm{An}$ association may, however, bring suit on behalf of its members provided that they will suffer the necessary cognisable injury. ${ }^{59}$

Nevertheless, the US Courts have appeared to be receptive to the public policy considerations weighing upon the standing doctrine. Chayes has argued ${ }^{60}$ that whilst early decisions attempted to assimilate class actions to ordinary litigation by treating the representative plaintiff as the focus of the standing issue, more recent decisions treat the class as the effective unit in the litigation. The court shifts its attention to the resolution of the legal issues in dispute between the class and class opponent. Hence, creative techniques have been employed to fashion exceptional rules which ultimately avoid the general standing principles.

In parentheses, it is worthwhile noting one such technique which permits the rigours of the standing doctrine to be mitigated, i.e., the use of an amicus curiae. An individual or pressure group, such as an environmental or civil liberties group, may apply for leave to intervene as an amicus even though it is not a party to the suit. Intervention is strictly in the discretion of the court ${ }^{61}$ and the consent of the parties may be required before it is permitted. In practice, however, the courts will readily favour a motion for intervention and the briefs of an amicus can be as influential as those of the parties. Leave to file a brief, however, only permits intervention in litigation already commenced by others. Thus the initiative of bringing suit does not lie with the amicus. Where such a challenge has already been undertaken, it is a particularly effective way for a pressure group to influence the decision of the court on the merits without necessarily having standing to appear as a party.

Other means of avoiding standing problems seem to be permitted in Federal class actions in the United States. These are of great interest partly because, like the English representative proceedings, they are rooted in Chancery practice, upon which Lord Eldon exercised such a powerful influence: each shares a common lineage. This makes a study of the U.S. jurisprudence of particular relevance. The issues are governed by Rule 23 of the Federal Rules of Civil Procedure which, in conformity with its English heritage, adopts the unity of interest theory. As with the English experience, a narrow interpretation of the theory has been found to be too restrictive, and the courts have responded by rejecting the idea that the representative parties and class members should

57. The person seeking relief must generally show that he has suffered "injury in fact": A ssociation of Data Processing v. Camp 25 L Ed. 2d 150 (1970) which can be defined as some actual or threatened injury; see, generally, Hough, [1986] Denning L. F. 85.

58. Havens Realty Corporation v. Coleman 71 L Ed. $2 \mathrm{~d} 214$ (1982).

59. Warth v. Seldin 45 L Ed. $2 d 343$ (1975).

60. (1976) 89 Harv. L. Rev. 1318, at p. 1464.

61. Re Ohlhauser's Estate (SD) 101 NW 2d 827. 
invariably be required to demonstrate a single and homogeneous interest in the suit. As in Duke of Bedford v. Ellis a recasting of the unity of interest or, in the U.S., the "typicality" requirement, opens the courthouse door to representation by non-interested parties. In U.S. Parole Commissioner v. Geraghty, ${ }^{62}$ for example, a prisoner, who had been denied parole by virtue of release guide-lines, challenged the guide-lines on behalf of himself and other prisoners. After certification of the suit but before the hearing of the matter by the Court of Appeals he was released and thus lost his personal interest in the suit. The Supreme Court rejected the submission that his action was mooted. A "live" dispute continued between the defendant and class members. In an interesting judgment the Supreme Court considered the role of the "standing" doctrine:

"The personal stake requirement is to assure that the case is in a form capable of judicial resolution. The imperative of a dispute capable of resolution are sharply presented issues in a concrete factual setting and self-interested parties vigorously advocating opposing positions. This can exist with respect to class certification notwithstanding the fact that the named plaintiff's claim on the merits has expired. Vigorous advocacy can be assured through means other than the traditional requirement of a personal stake in the outcome." 63

Blackmun J further conceded that whilst a class representative has the "right" to proceed if he obtains the certificate of the court, that right "is more analogous to the private attorney general concept than to the type of interest traditionally thought to satisfy the [standing] requirement." 64

Further, in Sosna v. Iowa $a^{65}$ the court stated that upon certification "the class of unnamed persons described in the certification acquired a legal status separate from the interest asserted by the appellant." 66

These decisions clearly reflect a move away from the traditional mould of single party litigation in which locus standi rules fall to be applied against the named defendant. Re-definition of the unit of litigation has taken place so as to focus upon the class with whom there remains a dispute with the defendant.

Although the reliance placed upon vigorous advocacy as a substitute requirement for traditional "standing" may be questioned, ${ }^{67}$ the above decisions suggest that the traditional private law model of dispute settlement can be made flexible. A personal stake, as the orthodox locus requirement, can be abandoned as the governing threshold issue if other factors enable the court to intervene; thus

62. 63 L Ed. 2d 479 (1980).

63. Ibid., at p. 495 (emphasis added).

64. Ibid..

65. 419 U.S. 393 (1975).

66. Ibid., at p. 399 .

67. It requires an analysis of what the representative might be in a position to argue and what might have been advanced by those represented although they are not, of course, before the court. Because the problem here is one of hypothesis, it is arguable that the court is in essence relying upon the proximity of relationship between the class advocate and the class which is the real nature of the locus test in representative type litigation. 
traditional locus standi qualifications are not by itself determinative of competence to sue.

\section{Safeguards}

In the United States, Rules of Court confer protection against any abuse of this form of proceeding. As soon as practicable ${ }^{68}$ after the commencement of proceedings, the putative class representative must obtain the leave, or the certificate, of the court that the proceedings are properly brought in class form. One of the principal objects of this is to ensure, inter alia, that the representative parties "fairly represent the class" 69 so as to avoid possible prejudice to their rights and interests.

\section{The state of the U.S. class action}

The euphoria which initially surrounded the expanded use of the class action in the United States has undoubtedly subsided; indeed in more recent years, in response to a more restrictive judicial stance towards it, ${ }^{70}$ its use appears to have declined. ${ }^{71}$ Its utility has been compromised by a number of converging factors embracing, for example, difficulties in identifying common questions which in turn renders the construction of a viable class a problematic issue. ${ }^{72} \mathrm{On}$ this side of the Atlantic, however, and especially in the context of mass tort litigation, it seems that confidence in the evolution of a class action remains high..$^{73}$

Significantly, perhaps, the creative use of the standing rules in public interest cases does not appear to have been the focus of the criticism levelled against the class action. ${ }^{74}$ In this regard the experiment has, perhaps, proved to be more satisfactory. It demonstrates, perhaps, that traditional locus standi rules can be remodelled without significant harm for the judicial process and this may encourage experimentation outside the class action strictu sensu. The lesson may be that, if other forms of representative style proceedings are to be permitted on this side of the Atlantic, the group must be capable of definition with reasonable

68. Rule 23 (c) (1).

69. Rule 23 (a) (4). In Hansberry v. Lee 311 U.S. 32 (1940) this was held to be satisfied if the interests of the absentee class members were assured. It may introduce some discretion into the standing question. 70. See Chayes, (1982) Harv. L. Rev. 1, at p. 28.

71. See H. Patrick Glenn (1986) 6 O.J.L.S. 252. He indicates that in 1976 over 3000 Federal class actions were filed but that this fell to a mere 987 in 1984 .

72. Ibid.

73. See, e.g., Irish Shipping v. Commercial Union Assurance Co. p.l.c. [1989] 3 All E.R. 853 expanding the categories of relief available in representative proceedings; and Chrzanowska v. Glaxo Laboratories Ltd. [1990]The Times, March 13th in which the court recognised its power to order that costs be met by members of the group represented who were likely to benefit from the proceedings. $R$. Tur advocates reform in the field of consumer protection so as to enable a more effective vindication of consumers' rights: (1982) 2 Legal Studies 135.

74. See H. Patrick Glenn, supra n. 70. Chayes appears to argue, however, that the approach to standing in class actions is not strictly consistent with orthodox rules but that it should nevertheless be welcomed: 96 Harv. L. Rev. 1, at p. 44. 
certainty. An additional reason for this would be the difficulty a representative plaintiff would encounter in establishing proximity of relationship with the members of a loosely defined group.

\section{Constitutional jus tertii in the United States}

Another line of United States authority, ${ }^{75}$ permitting the litigation by "strangers" of constitutional rights belonging to third parties, deserves to be noticed for its reliance on proximity as a technique for expanding cognisable forms of public interest litigation. Whilst it is not a true example of lowering the standing threshold since the litigant must satisfy normal standing rules, it does appear to accept that in limited and controlled circumstances litigation by a stranger of rights belonging to others may present a dispute capable of resolution.

Singleton v. Wulff ${ }^{76}$ provides an early example of this type of case. Here, a state anti-abortion statute was successfully challenged by licensed physicians on the ground that it violated the constitutional rights of their patients. The lifting of the prohibition on litigation by third parties was held to be permissible provided that the plaintiffs were "nearly as effective a proponent of the right" as the rightholder. ${ }^{77} \mathrm{~A}$ necessary if not sufficient condition for this would be the proximate relationship between the plaintiff and the right-holders. ${ }^{78}$ It would also be necessary to demonstrate that those represented suffered some impediment to the assertion of their own legal rights. ${ }^{79}$ A potential desire for privacy might, for example, dissuade individuals from taking proceedings in their own name thus permitting by default the violation of the rights otherwise guaranteed by the Constitution. ${ }^{80}$ Since the women and physicians enjoyed a close relationship, it was held that there would be no loss of effective advocacy if the case were litigated by the physicians. Subsequent developments have tended to expand this exceptional line of authority. ${ }^{81}$

Arguably, the postulated difficulties facing right-holders in enforcing their own

75. This topic is further discussed by Sedler, "Standing to Assert Constitutional fus Tertii in the Supreme Court", 71 Yale L.7. 599; also "Standing to Assert Constitutional fus Tertii", 88 Harv. L. Rev. 423.

76. 49 L Ed. 2 d 826 (1976).

77. Ibid., at pp. 833-4, citing Griswold v. Connecticut $14 \mathrm{~L}$ Ed. $2 \mathrm{~d} 510$, in which a licensed physician was allowed to assert the privacy rights of married patients to receive contraceptive advice. The court here emphasised the "confidential" nature of the relationship between the physicians and the right-holders and held that if the physicians were unable to sue on their behalf their rights may well be diluted because of their desire to avoid the publicity of litigation.

78. Ibid., at pp. 834-5.

79. Ibid., at p. 834 .

80. Ibid., at p. 835. Another relevant issue here was seen to be the imminent mootness of the litigation. Her pregnancy would be terminated either by natural or artificial means whereupon she would prima facie lose her standing to pursue the matter.

81. See, e.g., Carey v. Population Services 97 S. Ct. 2010 (1977) and Virginia v. American Booksellers Association 98 L Ed. 2 d 782 (1988). 
rights can all be overcome. ${ }^{82}$ The real foundation of this line of authority therefore rests upon the first ground only: that the nature of the relationship permits representation by a non-interested party who could otherwise not be heard on the issue. This is seen as generating "vigorous advocacy" by the representative of rights of the group thereby avoiding possible prejudice to those individuals. Proximity of relationship is thus the governing consideration.

Although these rules operate in the context of constitutional guarantees, this line of authority acknowledges that the traditional limits on third party litigation in the public interest are not inherent and that they can be changed. The radical shift towards a public law model of litigation through re-fashioned locus standi rules has not produced unacceptable results for the adversarial system in the United States even though the courts have experimented rather more boldly than their English counterparts.

\section{A unity of approach}

Common themes permeate all the above cases, whether decided under English or United States Federal law, demonstrating that representation is legitimate according to the nature of the relationship between the representative plaintiff and the group represented. In the English representative action, the rule is that a 'unity of interest' must bind the representative plaintiff and class members alike. Three affiliated conditions lie within the penumbra of the governing principle: the representative plaintiff and those represented must share a common interest in the proceedings, they should share a common grievance, and the relief sought should be beneficial to all. ${ }^{83}$ Although the precise ambit of these rules remains blurred, they are considered to embrace the additional requirement that the plaintiff must "fairly represent" the class. ${ }^{84}$ This essentially incorporates a rule requiring effective advocacy and forges an obvious link with jurisprudence in the United States. The overall effect is to relate legitimate representation to a synonymity, or proximity, of relationship between representative and group. This can be traced through all the decisions in which representation has been permitted. Thus locus standi for representatives appears to extend beyond cases in which the representative plaintiff demonstrates a "sufficient interest" of his own in the matter in issue to cases in which he enjoys a relationship of proximity with others who can demonstrate such a nexus.

Whilst Duke of Bedford $\mathrm{v}$. Ellis ${ }^{85}$ represents one of the most considered attempts at exploring the limits of permissible representation in English law, it is unlikely

82. Privacy objections carry little weight because it is open for the litigation to be conducted using a pseudonym: per Powell J in Singleton v. Wulff 49 L Ed. 2d 826 (1976), at p. 834 n. 6. An example is provided by Roe v. Wade 35 L Ed. 2d 147 (1973). Proceedings may, however, be conducted in open court.

83. Duke of Bedford v. Ellis [1901] A.C. 1; Smith v. Cardiff Corpn. [1954] 1 Q.B. 210; Pan Atlantic Assurance Co. Ltd. v. Pine Top Insurance Co. Ltd. [1988] 2 Lloyd's L.R. 505.

84. Taff Vale Rly. Co. v. Amalgamated Society of Railway Servants [1901] A.C. 426, at p. 438.

85. [1901] A.C. 1 . 
that the idea of proximity, will reach maturity as an identical twin of Lord Managhten's "unity of interest" test. Whilst the modern approach would not deny that, for example, the relief sought should not be detrimental to the interests of any involved, the courts do not seem to insist upon any requirement that the relief should actually benefit all. The representative party, normally lacks a personal stake in the outcome of the proceedings and his personal interests would therefore scarcely be advanced at all. Nevertheless, one similarity may be that the "proximity" and "unity of interest" tests each require that the representative should be capable of advancing all those matters which absentee group members might have advocated had they been before the court ${ }^{86}$ Thus proximity, may be closely related to, but not synonymous with, the "unity of interest" requirement in representative proceedings. Examples of sufficiently proximate relationships show that they may derive either from an experience shared by both the representative and the group represented, ${ }^{87}$ or from a close association with the group represented $;^{88}$ but these categories should not be regarded as closed.

However, the English courts have attempted to camouflage these developments behind the ostensible application of the "sufficient interest" formula and to mis-employ its apparent elasticity to hold that the representative litigants have "a sufficient interest" in their own right. This is to stretch the orthodox rules almost to breaking point. It would be desirable to recognise that different principles are in fact being applied in these cases; and the failure to articulate these principles has generated confusions. Exp. Sharp, for example, creates particular difficulties. The litigant had no greater interest than the public at large and essentially sought to act as a "private attorney-general". The award of standing in that case must be seen as controversial. Moreover, the technique employed to achieve this - the remoulding the litigation from a single party model into a quasi-representative one is a dangerous one if only because it is a course which could be followed in most public interest litigation with a highly corrosive effect for the doctrine of locus standi. It is difficult to see how, if standing is to survive at all, such an approach can be legitimate. ${ }^{89}$

86. In the United States vigorous advocacy may be a critical factor: Geraghty v. U.S. Parole Commissioner 63 L Ed. 2d 479. In English law, Megarry J in fohn v. Rees, supra n. 49, stressed that the class representatives should be able to put forward every view that could seriously be advanced by the class members themselves if they were before the court (although there may be problems with such an approach: supra n. 67. Note also the "fair representation" requirement (text to n. 84).

87. E.g., Roe v. Wade 35 L Ed. 2d 147 (1973) in which the prohibition on seeking abortion imposed by state laws had been encountered by members of the group and the representative plaintiff: see also $E x$ p. Bland, supra $\mathrm{n} .17$, and other decisions surveyed.

88. E.g., the shared trading experiences vis à vis the Duke in Covent Garden: Duke of Bedford v. Ellis [1901] A.C. 1 .

89. Subject to the exceptions formulated in the Fleet St. Casuals case which will permit standing to be awarded to a non-interested litigant in exceptional circumstances: supra n. 16. 


\section{Conclusion}

Representative and pressure group litigation is likely to become increasingly prevalent as the expense of litigation puts access to formal justice beyond the means of private individuals. The organisation and combining together of individuals to protect their interests is often essential since the individual alone is in an unequal match for public authorities. This follows a fortior in the case of the less affluent members of society. It is a process which should be nurtured since these private groups are likely to be more effective guardians of the public interest in enforcing the duties constraining public bodies than the archaic office of the Attorney-General ${ }^{90}$ who will not, it seems, take action against Central Government. Litigation by these groups advances public policy by giving effect to the legislative purpose in conferring rights in the first place.

In representative cases, the representative seems competent to proceed provided that he enjoys a proximate relationship with others who would have locus standi if they took proceedings in their own name. This is not a large advance in legal principle but in so far as it opens the court-house door to pressure groups and other bona fide representative litigants, it is surely much to be welcomed. The only matter for regret is that the courts have planted this seedling clandestinely in the tangled undergrowth of the orthodox standing rules. It is time to acknowledge it and to allow it to flourish amidst the other fruits of the common law. 